\title{
ПРОФЕСІЙНІ ТА ОСОБИСТІСНІ КОМПЕТЕНЦІЇ ФАХОВОЇ ПІДГОТОВКИ МЕНЕДЖЕРІВ ТУРИЗМУ
}

Лоїк Г. Б. Професійні й особистісні компетенції фахової підготовки менеджерів туризму.

У статті розглянуто питання особистісної компетениї фахової підготовки менеджерів туризму, проаналізовано їхні професійні та індивідуальні якості.

Ключові слова: компетенція, туристичний менеджмент, професійна діяльність.

Лоик Г. Б. Профессиональные и личностные компетенщии специальной подготовки менеджеров туризма.

В статье рассматриваются вопросы личностных компетенций профессиональной подготовки менеджсеров туризма, проанализированы их профессиональные и индивидуальные качества.

Ключевые слова: компетенция, туристический менеджмент, профессиональная деятельность.

Loic G. Professional and personal competences of special training managers of tourism.

The article deals withthe issue of personal jurisdiction of professional tourism training managers analyzed the ir professional and personal qualities.

Key words: competence, Tourism Management, professional activity.

Менеджер 3 туризму $\epsilon$ фахівцем, здатним вирішувати проблеми підвищення продуктивності праці та ефективності, конкурентоспроможності туристичного підприємства. Його завдання полягає у вивченні назрілих проблем пропонування та споживання туристичних послуг, проектуванні системи управління, яка забезпечила б успіх, і реалізація цього через людей i для людей. Отже, менеджер - це не просто керівник, а той, хто в змозі самостійно організувати експлуатацію туристичних ресурсів, вивчити туристичний ринок за допомогою маркетингу, керівник, який відчуває кон'юнктуру та динаміку попиту, перебудовує організацію з урахуванням вимог ринку. Менеджер - це керівник ринкової орієнтації, який забезпечує реалізацію головної мети туристичного підприємства - одержання прибутку через ринок, тобто надання туристичних послуг клієнтам.

Туристичний менеджмент - особлива, відносно відокремлена діяльність, що передбачає цілеспрямований вплив на працівників, управління та координацію операцій туристичних фірм в умовах ринку для досягнення певної мети, а саме одержання прибутку [3].

Загальні вимоги до менеджера туризму визначають ті знання, навички та вміння, які необхідні для фахівця певного туристичного профілю. Діяльність фахівця в галузі туризму складна і багатогранна, вона має бути спрямована на клієнтів, щоб їм було комфортно співпрацювати. Для цього менеджер має володіти культурою мислення, бути здатним лаконічно викласти свої думки як у письмовій, так і в усній формі. Для того щоб розумно поєднувати гуманітарні та соціально-економічні аспекти в туризмі, 
треба бачити їх взаємозв'язок, а це є виявом його компетенції.

Метою статті $\epsilon$ розгляд професійної компетенції майбутнього менеджера туризму як основного чинника формування кваліфікованого фахівця.

Розгляд генезису поняття «компетенції», а також провідних зарубіжних підходів до іiі формування надає можливість сформувати власні погляди на зміст та ключові характеристики компетенції менеджера туризму. Узагальнення наукових підходів до розуміння сутності компетенцій дозволяє обрати кілька визначень, які є найбільш показовими для з'ясування цього поняття $[1 ; 2 ; 5 ; 9]$ :

- компетенції - це набір стилів поведінки, яка дозволяє більш ефективно виконувати роботу;

- компетенції - це вимірювані, специфічні кластери поведінки працівника, які підлягають спостереженню та оцінці;

- компетенції $\epsilon$ набором моделей професійної поведінки, яку працівник має використовувати в межах своєї посади, щоб компетентно виконувати свої завдання і функції;

- компетенція - це основна характеристика людини, яка може бути мотивом, рисою характеру, навичкою, уявленням про самого себе, соціальною роллю або сукупністю знань;

- компетенція - сукупність знань, навичок і особистісних якостей, що дозволяє розв'язувати певну задачу (чи сукупність завдань).

Під час розгляду якостей людини, що сприяють формуванню певних трудових навичок i виконанню службових обов'язків, виокремлюють професійні та індивідуальні компетенції. До професійних найчастіше відносять ті, які стосуються виконання робіт, службової діяльності, посилюються під час професійної спеціалізації, а також відображають переважно раціональне в поведінці людини. Індивідуальними компетенціями вважаються ті, які виявляються за межами службових відносин: у побуті, у сім’і, у повсякденному спілкуванні з друзями, членами сім'ї, родичами та іншими людьми. У якості найважливіших особистісних якостей керівника розглядаються: доброзичливість, справедливість, колективізм, вміння тримати слово, чуйність, урівноваженість, скромність, зовнішня привабливість, життєрадісність, широта кругозору. До ділових якостей менеджера відносять працьовитість, ініціативність, акуратність, професіоналізм, організованість, старанність, енергійність, відповідальність, здібності до роботи, дисциплінованість.

Поняття «компетенція» тісно пов'язане із поняттям компетентності, деякі автори навіть ототожнюють компетентність 3 рівнем кваліфікації спеціаліста $[1 ; 8]$. Поєднання поняття «компетенції» з видами професійних якостей показано в табл. 1.

Водночас практика показує, що вказаний поділ умовний і часто не цілком відображає реальну дійсність. Річ у тому, що ефективність управління та успішність діяльності організації, безпосередньо пов'язані не тільки з суто професійними, а й з усіма іншими якостями керівника. Зокрема, наявні управлінські ситуації, успішне розв'язання яких залежить значною мірою 
саме від моральних якостей керівника. Не випадково низка джерел 3-поміж якостей керівника, які мають значення для ефективності управління організацією, не поділяє професійні та індивідуальні (особисті) [6]. Так, серед найважливіших якостей осіб, що приймають рішення в бізнесі, особлива увага приділяється професійно важливим якостями, що включають елементи кваліфікації та психофізіологічні властивості людини (рис.1).

\section{Диференціація понять «компетенції» і професійно важливих якостей (ПВЯ) персоналу}

\begin{tabular}{|c|c|}
\hline Компетенції персоналу & Професійно важливі якості персоналу (ПВЯ) \\
\hline $\begin{array}{l}\text { Компетенції персоналу - якості, важливі для } \\
\text { конкретної посади i/або конкретного } \\
\text { підприємства }\end{array}$ & $\begin{array}{l}\text { Професійно важливі якості персоналу - } \\
\text { якості, важливі для конкретної професії } \\
\text { безвідносно до конкретного підприємства }\end{array}$ \\
\hline $\begin{array}{l}\text { Компетенції посади - якості, важливі для } \\
\text { співробітника на певній посаді }\end{array}$ & $\begin{array}{l}\text { Корпоративні компетенції - якості, важливі } \\
\text { для будь-якого співробітника підприємства }\end{array}$ \\
\hline $\begin{array}{l}\text { Компетенції - якості, що свідчать про } \\
\text { спроможність людини якісно виконувати та } \\
\text { демонструвати у професійній поведінці вимоги } \\
\text { до посади або до підрозділу підприємства. } \\
\text { Залежать від особистісних властивостей людини }\end{array}$ & $\begin{array}{l}\text { Компетентність - якості, що свідчать про } \\
\text { знання, досвід, кваліфікацію людини } \\
\text { безвідносно до можливих форм професійної } \\
\text { поведінки. Не залежать від особистісних } \\
\text { властивостей людини }\end{array}$ \\
\hline $\begin{array}{l}\text { Межі компетенції (юридичний аспект) - } \\
\text { відсутність права вирішувати питання, що } \\
\text { виходять за межі посадових повноважень }\end{array}$ & $\begin{array}{l}\text { Межі компетенції (управлінський аспект) - } \\
\text { відсутність } \quad \text { спроможностей } \\
\text { здійснювати певні види діяльності }\end{array}$ \\
\hline $\begin{array}{l}\text { Компетенції в широкому розумінні включають } \\
\text { усі якості, важливі для професійної діяльності } \\
\text { персоналу: знання, уміння, навички (ЗУНи), }\end{array}$ & $\begin{array}{l}\text { Компетенції у вузькому розумінні включають } \\
\text { не всі якості, а тільки ті, що пов'язані } \\
\text { характером людини і можуть спостерігатися }\end{array}$ \\
\hline
\end{tabular}

\section{ПРОФЕСІЙНО ВАЖЛИВІ ЯКОСТІ}

\section{ЕЛЕМЕНТИ КВАЛІФІКАЦІї}

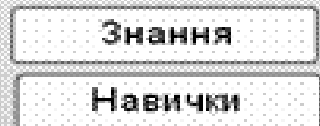

Здатністьдіяти відповідно стандартам

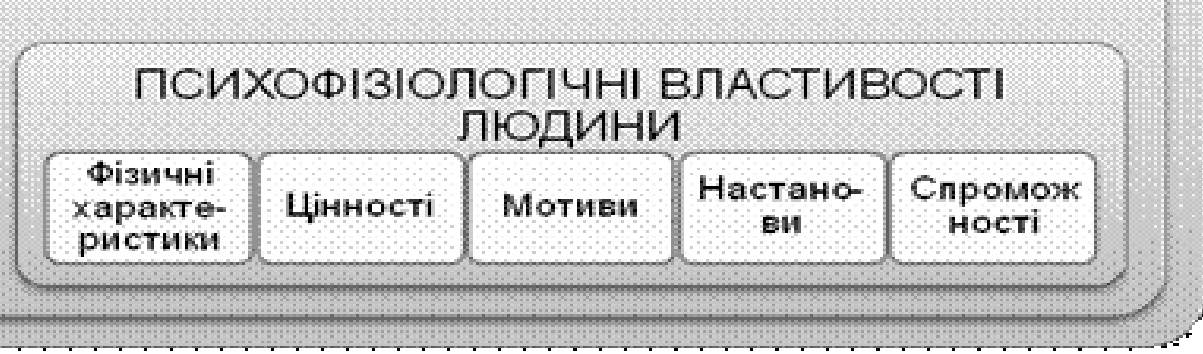

Рис.1. Психофізіологічні властивості людини і професійно важливі їі якості (за Одинцовим А.О.)

У процесі своєї діяльності менеджер має враховувати вплив своїх внутрішніх (особистих) якостей, своїх переваг і недоліків на виникаючі управлінські ситуації, на діяльність колективу і розвиток організації. Саме 
залежно від цих якостей ситуація або покращується і розв'язується позитивно, сприяє розвитку та посиленню очолюваного ним колективу, або навпаки, погіршується, сприяє виникненню нових проблем і веде до деградації, руйнування, ліквідації організації. Важко переоцінити значення для керівництва та управління комунікативних якостей менеджера таких, як товариськість, тактовність, уміння слухати і розуміти співрозмовника, вміння ладити 3 людьми, ввічливість, уміння психологічно коректно впливати на людей, уміння зберігати дистанцію. Необхідними для менеджера є його вольові якості - наполегливість, терпіння, самовладання, здатність до тривалої концентрації уваги. Також велике значення для ефективності роботи менеджера мають і його емоційні вияви: природність поведінки, невимушеність, щирість у спілкуванні, стійкість до стресу, емоційна стабільність, здатність до співпереживання. Слід відзначити й інші якості: які нерідко залишаються поза увагою: такі як алертність (розслаблена зібраність, миттєва готовність до адекватного дії без суєти й перенапруги) і тверезість (підхід до життя і ситуацій у ньому, за якого відбувається об'єктивна, істинна оцінка подій та дій усіх учасників, зокрема й самого себе). 3 іншого боку, для різних сфер діяльності менеджера - наукової, практичної, консультаційної - можна виокремити деякі якості, які мають для цих сфер особливе значення (рис. 2).

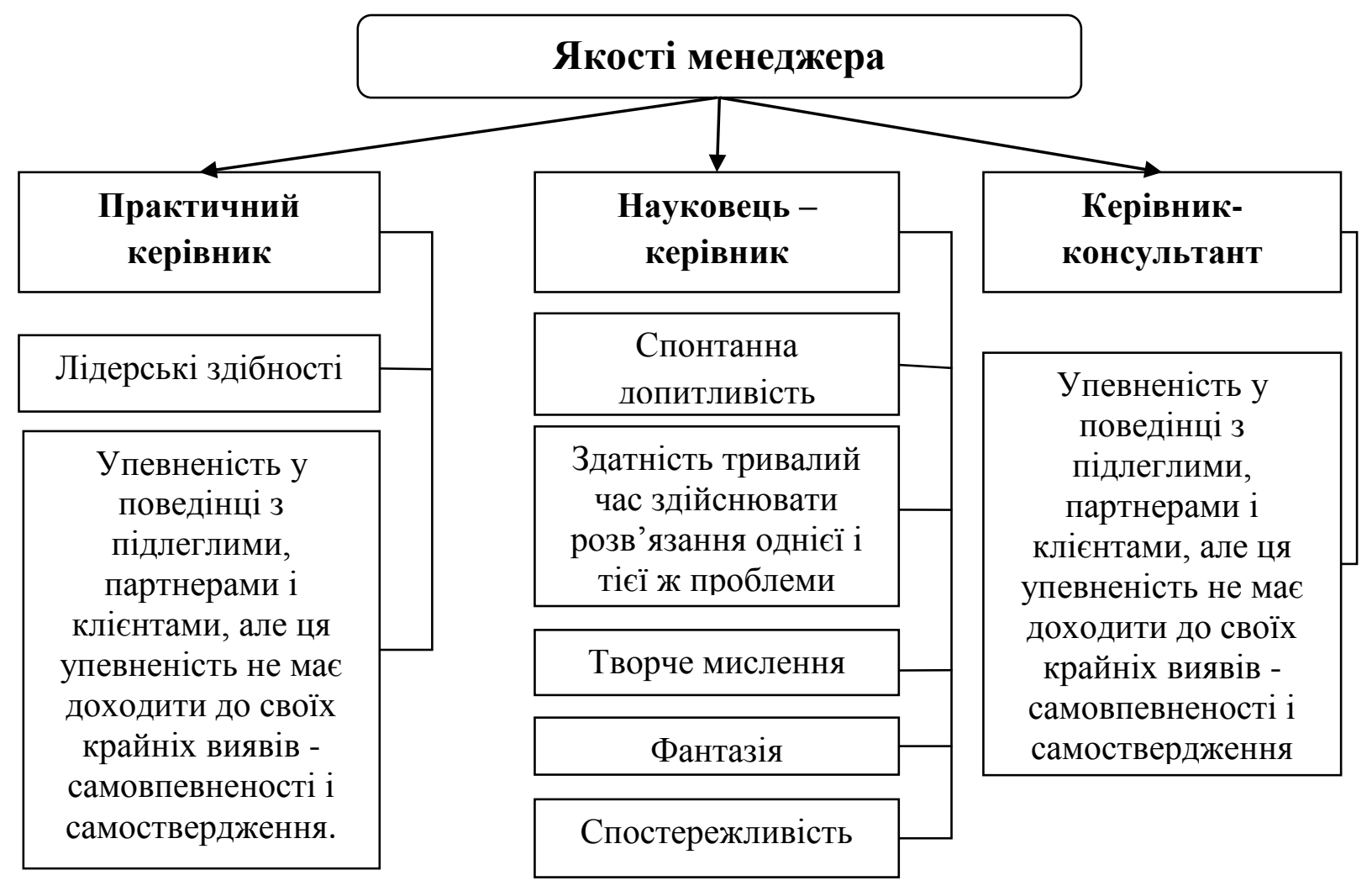

Рис. 2. Професійні якості менеджера

В умовах сучасного управління організацією менеджер повинен володіти низкою необхідних йому якостей, як особистісних, так і професійних. До професійних відносять ті, які характеризують будь-якого грамотного фахівця. 
Володіння ними є лише передумовою успішного виконання службових обов'язків. Такими якостями $\epsilon$ : високий рівень освіти, виробничого досвіду, компетентності у відповідній професії; широта поглядів, ерудиція, глибоке знання не тільки своєї, а й суміжних сфер діяльності; прагнення до постійного самовдосконалення, критичного сприйняття і переосмислення навколишньої дійсності; пошук нових форм і методів роботи, допомогу іншим в оволодінні ними, їх навчання; вміння раціонально використовувати час, планувати свою роботу.

У професійній діяльності, особливо на перших іï етапах, важко бути успішним в усьому. Не до всіх видів діяльності, властивих менеджеру, керівник-початківець виявляс однакові схильності і здібності. Та й не всі форми і методи, властиві сфері управління, засвоюються однаково успішно. У зв'язку з цим починаючому менеджеру важливо цілеспрямовано формувати свій індивідуальний стиль керівництва, який би враховував, із одного боку, його схильності і здібності, різного роду індивідуальні особливості, а з іншого - необхідність розвитку професійних якостей i самовдосконалення. Початківцю важливо мати адекватну самооцінку, усвідомлювати свої індивідуальні особливості, здібності і схильності, сильні і слабкі сторони характеру, а також способи і методи компенсації власних недоліків. Знання своїх якостей допомагають формувати індивідуальний стиль управління, сприяють підвищенню ефективності його діяльності, а значить успішності дій очолюваного ним колективу, стабільному розвитку організації. Для самостійної оцінки своїх якостей, зокрема мислення, менеджерських здібностей, вольового чинника, моральних якостей слід ураховувати думку оточуючих, використовувати самоспостереження, а також психологічні тести [10].

Слід ураховувати, що прагнення здійснювати організаторську діяльність і спілкуватися з людьми багато в чому залежить від змісту відповідних форм активності і від особливостей самої людини. Значною мірою це прагнення визначається суб'єктивною цінністю та значущістю для конкретної людини майбутніх результатів іiі діяльності і ставленням до осіб, 3 якими вона взаємодіє. Часто схильності з'являються під час таких видів діяльності i спілкування, які спочатку людині байдужі, але в міру залучення до них стають значущими. Важливими є постановка людиною перед собою цілей власного розвитку, а також зусилля, докладені людиною в досягненні поставленої мети. Для ефективного керівництва на будь-якому рівні управління мають значення дві групи індивідуальних якостей менеджера [7]:

1. Якості, знання, навички та вміння, які визначаються сферою діяльності організації (економіка, наука, культура, військову справу тощо). Тут велике значення мають освіта за профілем діяльності, досвід роботи в цій сфері, а також наявність особистих зв'язків у сфері діяльності організації.

2. Якості та навички, пов'язані з галуззю керівництва людьми і за своєю сутністю не залежать від сфери діяльності організації (лідерські якості та навички, ступінь розвитку вольової, інтелектуальної та емоційної сфери, моральні якості людини). Важливим $\epsilon$ те, що знання набуваються в 
результаті інтенсивних навчальних занять, повного занурення у службові ситуації, напрацьовуються і закріплюються відносно швидко за допомогою вчителів та за наявності джерел інформації (книг, документації тощо), а також практики роботи в конкретних життєвих ситуаціях.

Водночас воля, емоційна та інтелектуальна сфери, моральні якості керівника формуються протягом всього життя. Розвиток цих якостей потребує напруженої роботи над собою, усвідомлення і моральної оцінки життєвих ситуацій, конкретних подій, своєї ролі і місця в них. Це процес тривалий, і різкі стрибки в ньому рідкісні і малоймовірні.

Особистісні якості менеджера мало чим відрізняються від якостей інших працівників, які бажають, щоб їх поважали і з ними рахувалися. Варто назвати:

1. Високі моральні стандарти.

2. Фізичне і психологічне здоров'я.

3. Внутрішня і зовнішня культура, справедливість, чесність.

4. Чуйність, дбайливість, доброзичливість.

5. Оптимізм, упевненість у собі.

Але володіння ними лише передумова успішного керівництва, оскільки менеджером роблять людину не професійні або особистісні, а ділові якості, до яких необхідно віднести:

1. Вміння організувати діяльність підлеглих, забезпечити їх усім необхідним, ставити і розподіляти завдання, координувати і контролювати їх виконання.

2. Домінантність, честолюбство, високий рівень домагань, прагнення до незалежності, влада, лідерства в будь-яких обставинах, а часом і за всяку ціну, сміливість, рішучість, напористість, воля, безкомпромісність.

3. Контактність, комунікабельність, уміння прихилити до себе людей, переконати в правильності своєї точки зору (фахівці вважають, що 80 відсотків знань менеджера мають складати знання про людину).

4. Ініціативність, оперативність у вирішенні проблем, здатність концентруватися на головному.

5. Уміння керувати собою, своєю поведінкою, стосунками з оточуючими.

6. Прагнення до перетворень, нововведень, готовність йти на ризик i вести за собою підлеглих.

Вимоги до менеджерів щодо цих якостей на різних рівнях управління неоднакові. На низьких рівнях цінуються рішучість, комунікабельність, деяка агресивність; на середніх - більшою мірою вміння спілкуватися, почасти концептуальні навички; на вищих рівнях на перше місце висуваються вміння стратегічно мислити, оцінювати ситуацію, ставити нові цілі, здійснювати перетворення, організовувати творчий процес підлеглих.

Оскільки менеджер будь-якого рівня не тільки організовує і спрямовує роботу співробітників, але і за необхідності впливає на їх поведінку, зокрема і в позаслужбовий час, він має бути добре підготовлений педагогічно. 


\section{Література}

1. Арефьев А. О. Управление компетенцией и ротация человеческих ресурсов проектноориентированного предприятия [Электронный ресурс] / А. О. Арефьев, А. Д. Баженов: Режим доступа: http://www.iteam.ru/publications/project/section 39/article 2499/

2. Вартанова О. В. Компетенція персоналу: теоретичне визначення та складові / О. В. Вартанова, С. П. Скляр // Актуальні питання теорії і практики менеджменту: матеріали першої всеукр. наук.-практ. конф. студентів і молодих учених, 17-19 березня 2010 р. - Луганськ: СНУ ім. В. Даля, 2010. - С. 274-276.

3. Информационные технологии в бизнесе. Энциклопедия / под ред. Милана Желены. - Санкт-Петербург, Москва, Харьков, Минск: ПИТЕР, 2002. - 1120 с.

4. Кабушкин Н. И. Менеджмент туризму / Н. И. Кабушкин. - Минск : ТОВ Новое знание, 2001.

5. Клецова К. В. Формування компетенцій персоналу як основа забезпечення його конкурентоспроможності на ринку праці / К. В. Клецова // Вісник Східноукраїнського національного університету імені Володимира Даля. - 2010. - №1 (143). Ч. І. - С. 144-151.

6. Одинцов А. О. Менеджмент организации. Вступление в специальность. - М.: Екзамен, 2004. - С. 96.

7. Психология личности / под ред. Ю. Б. Гиппенрейтер, А. А. Пузирея. - М. : Просвещение, 1992. - С. 152.

8. Скляр С. П. Сутність та складові компетенції персоналу [Електронний ресурс] Режим доступу: http://www.nbuv.gov.ua/portal/Soc_Gum/Emp/2011_23_1/26Sklar.htm

9. Стратегічне управління персоналом підприємства в умовах сучасного розвитку ринку праці: [монографія] / [І. Р. Бузько, О. В. Вартанова, Г. О. Надьон та ін.]. - Луганськ. Вид-во СНУ ім. В. Даля. - 2009. - 304 с.

10. Сусанна О. М. Ваш психологический портрет / О. М. Сусанна. - Минск : Пламя, 1997.

Стаття надійшла до редакції 25.05.2012 р.

УДК [37.091.2: 030] - 057.87

В. В. Кирикилищя, acniрант, Волинський національний університет імені Лесі Українки

\section{КРИТЕРІАЛЬНО-РІВНЕВА ХАРАКТЕРИСТИКА АКТИВІЗАЦЇ̈ НАВЧАЛЬНО-ПІЗНАВАЛЬНОЇ ДІЯЛЬНОСТІ СТУДЕНТІВ У ПРОЦЕСІ РОБОТИ ЗІ СЛОВНИКАМИ}

\footnotetext{
Кирикиличя В. В. Критеріально-рівнева характеристика активізаиії навчальнопізнавальної діяльності студентів у процесі роботи зі словниками.

Статтю присвячено теоретичному обтрунтуванню критеріїв та показників активізаиії навчально-пізнавальної діяльності студентів немовних спеціальностей у процесі роботи зі словниками, а також аналізу рівнів їх сформованості.

Ключові слова: критерії, показники, рівні, активізація, навчально-пізнавальна діяльність, робота зі словниками.

Кирикилица В. В. Критериально-уровневая характеристика активизации учебнопознавательной деятельности студентов в процессе работы со словарями.

Статья посвящена теоретическому обоснованию критериев и показателей активизации учебно-познавательной деятельности студентов в процессе работы со словарями, а также анализу уровней их сформированности.

Ключевые слова: критерии, показатели, уровни, активизация, учебно-познавательная деятельность, работа со словарями.

Kirikilitsa V. Criterial feature-level activation of the educational-cognitive activity of students in the process of working with dictionaries.

The article is devoted to theoretical grounding of criteria and indices of students' knowledge and cognitive activities activation during dictionary activity, also levels of their formation are analyzed.

Key words: criteria, indices, levels, activation, knowledge and cognitive activities, dictionary activity.
} 